\title{
The Role of Digital Marketing in Engaging SMEs and Education Institution in Emerging Economy
}

\author{
NOERLINA \\ Information Systems Department, School of Information Systems, \\ Bina Nusantara University, Jakarta, INDONESIA \\ TIRTA NUGRAHA MURSITAMA \\ International Relations Department, Faculty of Humanities \\ Bina Nusantara University, Jakarta, INDONESIA
}

\begin{abstract}
In marketing strategy, companies must professionally understand online social marketing campaigns and understand how to implement them effectively. The consideration of using digital marketing in the company is related to cost efficiency and has a major influence on improving the company's business performance. This study shows how digital marketing is needed in almost all institutions in developing countries, including in education and SMEs, how it impacts the performance of institutions, and what strategies need to be applied to achieve the targets of higher education institutions. Digital marketing strategies in Indonesian institutions need to sort out which digital media are suitable for readers or visitors according to generational groups. It is also necessary to consider traditional marketing for the target market who have limited access to technology, such as internet access is not yet spread evenly in several areas in developing countries. Digital marketing makes it easier for education institution and SMEs to provide information and interact directly with consumers, expand market share and increase awareness.
\end{abstract}

Key-Words: - Digital Marketing, Marketing Strategy, Emerging economy, SMEs, Education institution.

Received: May 12, 2021. Revised: January 24, 2022. Accepted: February 4, 2022. Published: February 18, 2022.

\section{Introduction}

In today's digital era, business and technology are changing rapidly. The need for business with the help of technology to facilitate all existing activities is increasing. Technology-based business strategy and planning is an important step in winning business competition. Companies need to implement the right strategy to maintain and increase loyal customers. Marketing is an important part of a company where a strategy is needed to introduce a product or service to potential consumers. To implement a better marketing strategy than competitors, companies need to know everything about their customers, from what consumers need and how they can be satisfied. From the identification of these needs, products can be created according to the market needs [1].

Along with technological advances, the business world is also experiencing an increasingly varied trend of change. From the marketing process in the company, it also began to shift to the digital marketing trend. To increase product sales from the company, the application of digital marketing is mandatory in the digital era. The application of digital marketing in general is to increase the number of consumers by using a technology and internet approach in accordance with the current direction of world development towards the industrial revolution 4.0. Today's business world relies heavily on digital marketing such as search engine optimization (SEO), search engine marketing (SEM), influencer marketing, content marketing, content automation, e-commerce marketing, and social media marketing, and others. It becomes a basic need in technology-based business in the future [2].

The consideration of using digital marketing in the company is related to cost efficiency and has a major influence on improving the company's business performance. Knowing which social media sites are used by the target market is another key in ensuring that digital marketing will succeed in connecting consumers according to the company's target. The effectiveness of marketing using the internet between different businesses needs to be analyzed further because of the different characteristics of the company [2]. University as a higher education institution has different 
characteristics from companies that focus on profit, and it needs a different strategy in implementing digital marketing. Digital marketing in higher education has more focus on attracting prospective students who are academically potential and provide more benefits to society and the country in educating the nation. This article shows how digital marketing is needed in higher education institutions, how it impacts the performance of institutions, and what strategies need to be applied to achieve the targets of higher education institutions.

To present the results of the research in this article, the structure of the article is structured by starting with a discussion of related previous studies, followed by a discussion of case studies in education institution and the appropriate strategies that can be applied and conclusions from the research discussion.

\section{Theoretical Review}

Various previous studies on digital marketing have been carried out by many researchers in the world. Digital marketing can be formulated as a company marketing strategy using the internet and digital media such as blogs, emails, websites, and others. Marketing activities include the process of planning concepts, their implementation, pricing strategies, and product promotion and distribution, with the aim of building a mutual relationship between producers and consumers [3]. The development of the digital world is currently being used to support the company's marketing through the activities of introducing the company's products online and packaged in an attractive way so that it has a significant influence on the company's product sales [4].

The Internet and related digital technology platforms present opportunities as well as threats to organizations. For example, various online companies such as Amazon, iTunes and other online companies get very significant benefits and advantages in their business processes by utilizing existing technology. Many consumers use social networks such as Facebook, Google+, Twitter, and other digital media as part of their daily lives. Companies that can seize opportunities from current societal trends that cannot be separated from technology will gain competitive advantages and can increase the company's reputation to become a worldwide brand [5].

In a marketing strategy, companies professionally must understand online social marketing campaigns and understand how to implement them effectively as seen from the achievement of measurable performance indicators. The development of market dynamics around the world is changing in relation to the presence of the younger generation with the ability and need for accessibility to social media and its use [2]. Previous research has shown that millennials have a high interest and preference for certain forms of online promotion and advertising. The digital marketing strategy as one of the strategies considered is more effective in capturing the attention of the millennial generation, motivating and encouraging repeat visits to business websites, and encouraging them to write their experiences and reviews online because this pattern of review results is very useful for companies to attract attention in a wider market share [6].

Other research also states the importance of entrepreneurial values in supporting every aspect of success from an early age. In the success of the digital marketing program, one thing that needs to be considered is the awareness of the value of entrepreneurship and government support [12].

\section{Method}

The research method in this paper uses a literature review approach from previous research that discusses digital marketing strategies. After seeing the results of previous research, mapping was carried out on how this digital marketing strategy can also be applied in higher education institutions or education institution. With the case study approach, it can be formulated what strategies can be carried out at this non-profit institution by looking at the consumer category, namely students who enter the millennial generation group.

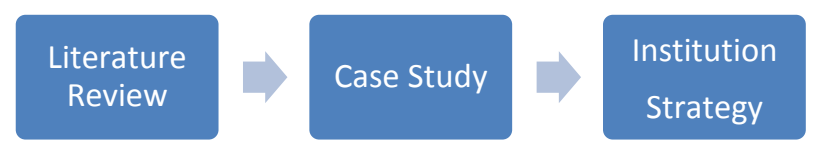

Fig. 1: Research Stages

\section{Result and Discussion}

To find out how previous research related to digital marketing, a literature review was carried out. The search for research references is also done by focusing on digital marketing in companies and in higher education institutions. One of the results of research in the US states that students at education institution who fall into the category of the millennial generation are a generation that is very highly dependent on the internet, so it is the right 
strategy if the institution implements a digital marketing strategy[6].

Previous research related to the strategy and implementation of digital marketing has also become a concern since the increasing need for the internet, especially in business processes and to win the competition. The following is a summary of several previous studies in table 1 .

Table 1. Previous Studies

\begin{tabular}{|c|c|c|}
\hline Authors & Methodology & Findings \\
\hline $\begin{array}{ll}\text { Bala } \quad \& \\
\text { Verma } \\
(2018)\end{array}$ & $\begin{array}{l}\text { Source of } \\
\text { secondary data. } \\
\text { This article was } \\
\text { compiled based } \\
\text { on a literature } \\
\text { review and } \\
\text { information } \\
\text { sources from the } \\
\text { internet. }\end{array}$ & $\begin{array}{l}\text { Consumers tend to } \\
\text { search for information } \\
\text { through the internet to } \\
\text { find the best offer of } \\
\text { the goods needed } \\
\text { compared to making } \\
\text { direct transactions } \\
\text { with traditional } \\
\text { methods. }\end{array}$ \\
\hline $\begin{array}{l}\text { Redjeki \& } \\
\text { Affandi } \\
\text { (2021) }\end{array}$ & $\begin{array}{lr}\text { A } & \text { qualitative } \\
\text { review } & \text { approach } \\
\text { uses riterature } \\
\text { review r to } \\
\text { examine and } \\
\text { provide } & \text { solutions } \\
\text { to r research } \\
\text { issues. }\end{array}$ & $\begin{array}{l}\text { Digital marketing is } \\
\text { very beneficial for } \\
\text { entrepreneurs in the } \\
\text { category of micro, } \\
\text { small and medium- } \\
\text { sized enterprises } \\
\text { (MSME) in Indonesia } \\
\text { because it can increase } \\
\text { the sales turnover of } \\
\text { MSME. However, the } \\
\text { application of digital } \\
\text { marketing is still very } \\
\text { limited in Indonesia } \\
\text { due to several factors } \\
\text { such as limited } \\
\text { knowledge and } \\
\text { mastery of technology, } \\
\text { limited access and } \\
\text { inadequate } \\
\text { infrastructure. }\end{array}$ \\
\hline $\begin{array}{l}\text { Kannan \& } \\
\text { Li (2016) }\end{array}$ & $\begin{array}{l}\text { Develop a } \\
\text { framework for } \\
\text { research in } \\
\text { digital marketing } \\
\text { that highlights } \\
\text { touchpoints in } \\
\text { the marketing } \\
\text { process and their } \\
\text { impact. }\end{array}$ & $\begin{array}{l}\text { Research issues and } \\
\text { updates in research } \\
\text { related to digital } \\
\text { technology and digital } \\
\text { marketing (consumer } \\
\text { behavior, social media } \\
\text { and UGC, platforms } \\
\text { and } \\
\text { markets, two-sided } \\
\text { engines, } \\
\text { contextual } \\
\text { interactions). }\end{array}$ \\
\hline $\begin{array}{l}\text { Smith, K.T } \\
(2012)\end{array}$ & $\begin{array}{l}\text { Data from a 3- } \\
\text { year period } \\
\text { (2009 to 2011) } \\
\text { by conducting a } \\
\text { survey to the } \\
\text { millennial }\end{array}$ & $\begin{array}{l}\text { Digital marketing } \\
\text { strategy as one of the } \\
\text { strategies considered is } \\
\text { more effective in } \\
\text { capturing the attention } \\
\text { of the millennial }\end{array}$ \\
\hline
\end{tabular}

\begin{tabular}{|c|c|c|}
\hline Authors & Methodology & Findings \\
\hline & $\begin{array}{lr}\text { generation } & \text { at } \\
\text { Southwest } & \text { US } \\
\text { University. } & \end{array}$ & $\begin{array}{l}\text { generation, motivating } \\
\text { and encouraging } \\
\text { repeat visits to } \\
\text { business websites and } \\
\text { encouraging them to } \\
\text { write their experiences } \\
\text { and reviews online. }\end{array}$ \\
\hline $\begin{array}{l}\text { Todor, R.D } \\
\text { (2016) }\end{array}$ & $\begin{array}{l}\text { Literature review } \\
\text { in the form of a } \\
\text { comparison of } \\
\text { the advantages } \\
\text { and } \\
\text { disadvantages of } \\
\text { digital marketing } \\
\text { with traditional } \\
\text { marketing. }\end{array}$ & 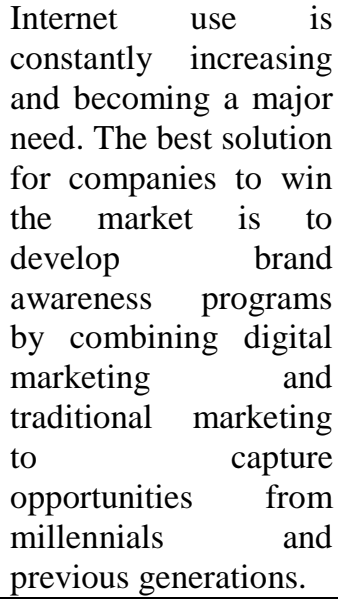 \\
\hline
\end{tabular}

Looking at the conditions in Indonesia, the number of education institution is 4,576 institutions, with the number of faculty members amounting to 294,339 lecturers and the number of students amounting to $8,833,078$ [7]. In accordance with the results of the 2020 population census (SP2020) by the Central Statistics Agency (BPS) it is stated that the composition of the population in Indonesia is dominated by generation $\mathrm{Z}$ and millennials. Generation $Z$ is the generation born from 1997 to 2012, while the millennials are those born from 1981 to 1996 . The percentage of the population of Generation $\mathrm{Z}$ is $27.94 \%$ and the millennial generation is $25.87 \%$ [8].

Based on the condition of education institution, the target consumers are students and prospective students as well as their parents. Faculty members, and education staff consisting of various generations, it is necessary to do a combination of marketing strategies to reach various generations. Traditional marketing is still needed and is aimed at attracting educational staff and faculty members and parents of students and parents of prospective students who may still have limitations in internet access and technological capabilities. As for digital marketing, it is implemented as part of a marketing strategy in facing the industrial revolution 4.0 where the main actors are the future generation, including generation $\mathrm{Z}$ and the millennial generation. The need for digitization in various aspects of life is the main thing and becomes a general need in various 
aspects of life including business, in this case, it is in every aspect of the business that exists in companies and education institution, including strategies for implementing digital marketing to win the competition.

The case study researched is one of the leading private education institution in Indonesia which is known as a strong university in the field of information technology. Where the use of digital in all aspects of higher education business processes is applied, such as:
a. Digital content
b. University TV
c. iTunes U, Udemy, Youtube
d. University online store
e. Digitization of University Catur Dharma

"IT-based business process" is the main strategy in every aspect of the business process at university towards readiness to face the industrial revolution 4.0. In improving competitiveness, the university's vision and mission have been directed towards globally recognized institutions, with strategies for achieving international recognition in various aspects such as reputable international research and publications, international student exchanges, visiting professors from overseas education institution, international recognition from QS, THE, and other international institutions.

Based on the above discussion, the conceptual framework of the strategy for implementing digital marketing in education institution can be formulated as follows.

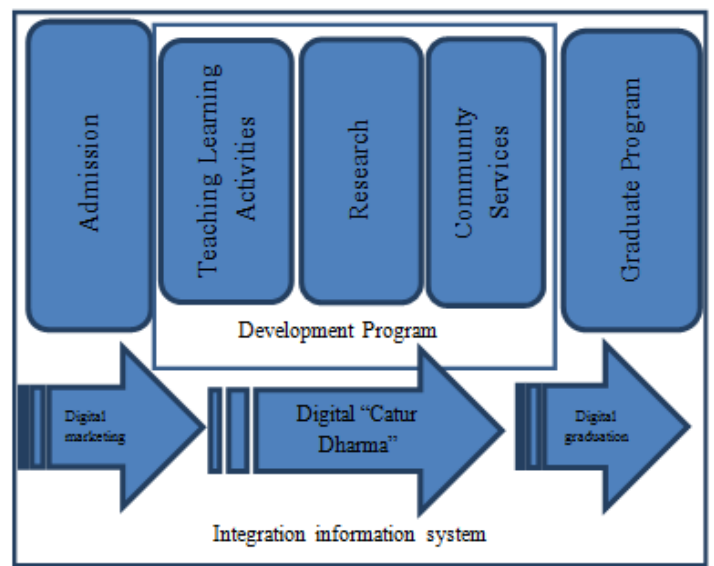

Fig. 2: Digitization of Higher Education Business Processes

Source: Author (2021)

Conceptual framework of the strategy for implementing digital marketing in SMEs can be formulated as follows.

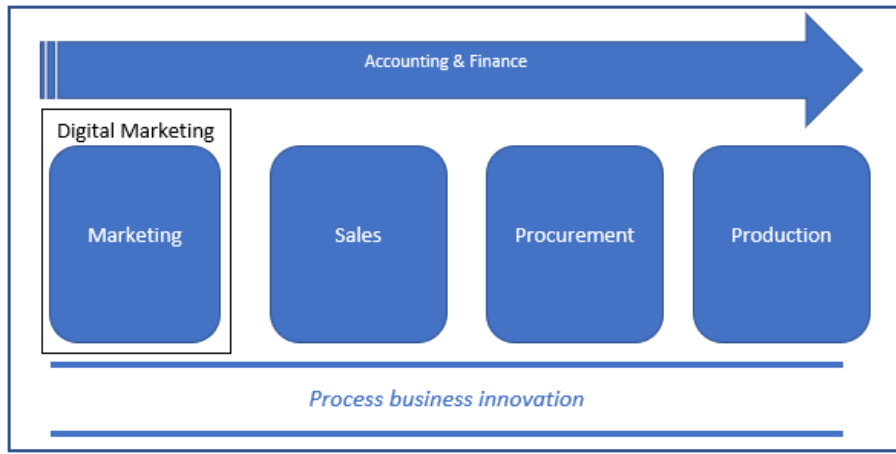

Fig.3: Digital Marketing of SMEs Business Processes

Source: Author (2021)

Considering the characteristics and conditions of developing countries, the digital marketing strategies in institution that can be applied are:

\section{Website}

The presence of a university website is mandatory now. In addition to introducing education institution, it is also to recruit prospective students and faculty members both domestically and abroad. In addition, it will also increase the opportunities for cooperation with other institutions, especially overseas. Therefore, it has become common that a university website must be at least dual language (the language in which the institution is located and English).

\section{SEO (Search Engine Optimization)}

SEO is a strategy that education institution can use to optimize their websites to get top rankings from an online search process. By implementing SEO, it is hoped that education institution will get opportunities to increase new student registrations and become a place of choice for faculty members and education staff because they appear more often on search sites.

The importance of the educational institution's web using the concept of SEO in addition to increasing intake as well as to spread knowledge, where higher education is a center of knowledge and has a social obligation to improve the welfare of the community.

\section{Content Marketing}

Education institution are expected to plan and build interesting content about their institutions. This content marketing will attract the public to understand how the performance and achievements of higher education and the vision and mission will be achieved, thus motivating the content marketing readers to make the university as a place of choice for further study.

\section{Social Media Marketing}


The use of social media is one strategy to introduce and make the public more aware of the presence and contribution of education institution. This will have the impact of increasing the recognition of brands from education institution and SMEs in the community, especially in the current digital era where today's society is very active in accessing social media such as Instagram, Twitter, and others.

\section{Blogs}

The existence of blogs is a special attraction because students or faculty members and education staff can talk in more relaxed atmosphere about their own experiences and opinions. These blogs can be used as a tool to provide knowledge to online media readers what they will get by joining certain education institution and SMEs and what the actual conditions they will face. With the right direction, the contents of blogs can display an interesting atmosphere and attract readers to get to know the university better.

\section{Affiliate Marketing}

Education institution and SMEs may cooperate with other services or institution sites to refer visitors to the their website. An example is hosting video ads on YouTube. With this strategy, visitors can see how the environment of the education institution and SMEs and their lecturers. Many wellknown education institution abroad apply this strategy so that we can enjoy the facilities and atmosphere by just watching videos from the college so that interest will be higher.

According to previous research, digital marketing has significant effect on quality service, and this support the improvement of SMEs sales performance. Digital marketing directly also has significant effect on sales performance [9]. Innovation by implementing digital marketing is one of the important strategies in increasing the company's competitiveness [10]. Some of the latest digital marketing techniques that can be used such as Digital Marketing strategies Using Cloud Marketing, email marketing. SMEs and education institution that implement digital marketing need to improve firms technological capabilities in all level of their management [11].

\section{Conclusion}

By implementing a digital marketing strategy using all-digital media, it is possible to do everything very quickly in seconds. The feedback obtained can also be measured in real time and precisely. So that the success of this digital marketing implementation can be immediately known, such as information on how many visitors enter the website, how long visitors see the product, and it is also possible to convert performance improvements, especially new student registrations from every digital media that is broadcast. In addition, looking at the reach with digital marketing, it is also wider geographically. Only by utilizing the internet, the spread of the brand can be throughout the world in just an instant.

Education institution in optimizing the use of digital marketing strategies need to pay attention to the target community who reads the information. Digital marketing strategies in education institution need to sort out which digital media are suitable for readers or visitors according to generational groups. It is also necessary to consider traditional marketing for the target market who have limited access to technology, such as internet access is not yet spread evenly in several areas in Indonesia.

Further research needs to pay attention to the differences in the characteristics of digital marketing implementation in developed countries compared to developing countries especially associated with educational institutions and SMEs.

\section{Acknowledgement:}

This research is supported by Ministry of Education and Culture of Indonesia, Directorate General of Higher Education, as a part of "Konsorsium Riset Unggulan Perguruan Tinggi" research grant entitled "Model Tata Kelola Ekonomi Digital di Era Revolusi 4.0: Regulasi, Inklusi Finansial, dan Inovasi Teknologi" with contract number 234/E4.1/AK.04.PT/2021; 3582/LL3/KR/2021.

\section{References:}

[1] Todor, R. D., Blending traditional and digital marketing, Bulletin of the Transilvania University of Brasov, Series I: Engineering Sciences, Vol. 9, No. 1, pp. 51-56, 2016, Available at: http://ezproxy.leedsbeckett.ac.uk/login?url=htt p://search.ebscohost.com/login.aspx?direct=tru $\mathrm{e} \& \mathrm{db}=\mathrm{a} 9 \mathrm{~h} \& \mathrm{AN}=116699220 \&$ site $=$ edslive \&scope $=$ site.

[2] Bala, M. and Verma, D., A Critical Review of Digital Marketing, International Journal of Management, Vol. 8, No. 10, 2018, pp. 321339.

[3] Kleindl and Burrow, E-Commerce Marketing, USA: Thomson, 2005. 
[4] Struggles, H., The Adoption of Digital Marketing in Financial, Services Under Crisis, 2009.

[5] Chaffey, D. F. E. C., Digital Marketing Strategy, Implementation and Practice Sixth Edition, Journal of Chemical Information and Modeling, 2016.

[6] Taken Smith, K., 'Longitudinal study of digital marketing strategies targeting Millennials, Journal of Consumer Marketing, Vol. 29, No. 2, 2012, pp. 86-92. doi: $10.1108 / 07363761211206339$.

[7] https://pddikti.kemdikbud.go.id/

[8] https://www.bps.go.id/

[9] Djakasaputra, A., et al. "Empirical study of Indonesian SMEs sales performance in digital era: The role of quality service and digital marketing." International Journal of Data and Network Science 5.3 (2021): 303-310.

[10] Noerlina, F. Alamsjah, and T. N. Mursitama, "Service innovation and its impact on firm performance: A systematic literature review," IOP Conf. Ser. Earth Environ. Sci., vol. 729, no. $1, \quad 2020$, doi: $10.1088 / 1755-$ $1315 / 729 / 1 / 012128$

[11] Noerlina, et al. "Technological Capabilities and Value Chain of the Foreign Firms in Indonesia's High-Tech Industries", 2021. SCOPUS, www.scopus.com, doi:10.1109/ICIMTech53080.2021.9535032.

[12] Tambunan K.E, Mintarti S.U.W., Wahjoedi, Wahyono, H. "Internalization of Entrepreneurship Values for Entrepreneurship Learning in Vocational Schools", WSEAS Transactions on Environment and Development, vol. 17, pp. 19-27, 2021.

\section{Sources of Funding for Research Presented in a Scientific Article or Scientific Article Itself}

This research is supported by Ministry of Education and Culture of Indonesia, Directorate General of Higher Education, as a part of "Konsorsium Riset Unggulan Perguruan Tinggi" research grant entitled "Model Tata Kelola Ekonomi Digital di Era Revolusi 4.0: Regulasi, Inklusi Finansial, dan Inovasi Teknologi" with contract number 234/E4.1/AK.04.PT/2021; 3582/LL3/KR/2021.

\section{Creative Commons Attribution License 4.0 (Attribution 4.0 International, CC BY 4.0)}

This article is published under the terms of the Creative Commons Attribution License 4.0 https://creativecommons.org/licenses/by/4.0/deed.en US 